\title{
KETAHANAN PANGAN RUMAH TANGGA TANI PERKOTAAN DAN PERDESAAAN KABUPATEN GUNUNGKIDUL
}

\section{Food Security in Urban and Rural Farm Household in Gunungkidul}

\author{
Dyah Ayu Widyanitha, Suhatmini Hardyastuti, Jangkung Handoyo Mulyo
}

\begin{abstract}
This research is conducted (1) to analyze share of farm household food expenditure for the urban and rural, (2) to analyze the level of urban and rural energy farm household, (3) to analyze the level of household food security urban and rural farm, (4) to analyze desirable dietary pattern of urban and rural farm household, (5) to understand influencing factor of score food security farm household. The primary method for this research use descriptive analysis, sampling is done by using simple random method with 25 urban and 25 rural farm household in Gunungkidul. The data was analyzed by independent sample t-test and multiplier regression analysis by Ordinary Least Square (OLS). The results showed that (1) the share of farm household food expenditure in urban areas is lower than the share of food expenditure of farm households in rural areas, (2) the adequacy of farm household energy in rural areas is higher than the farm households in urban area, (3) urban households food secure $20 \%$, vulnerable food $40 \%$, less food $12 \%$, food insecurity $28 \%$, yet rural household food secure $16 \%$, vulnerable food $48 \%$, less food $4 \%$, food insecurity $32 \%$, (4) food pattern expectations farm households in urban areas are not higher than the expectation of food patterns in rural areas, (5) factors that positively affect the food security of farm households are farm household income and location (urban and rural).
\end{abstract}

Keywords: The share of food expenditure, energy sufficiency, food security, urban and rural.

\section{INTISARI}

Penelitian ini memiliki tujuan untuk (1) menganalisis pangsa pengeluaran pangan rumah tangga tani perkotaan dan perdesaan (2) menganalisis tingkat kecukupan energi rumah tangga tani perkotaan dan perdesaan (3) menganalisis tingkat ketahanan pangan rumah tangga tani perkotaan dan perdesaan (4) menganalisis pola pangan harapan rumah tangga tani perkotaan dan perdesaan (5) mengetahui faktor- faktor yang mempengaruhi ketahanan pangan rumah tangga tani. Metode dasar dalam penelitian ini adalah dengan menggunakan metode deskriptif, penentuan sampel dilakukan dengan menggunakan metode acak sederhana yaitu 25 rumah tangga tani perkotaan serta 25 rumah tangga tani perdesaan di Kabupaten Gunungkidul. Analisis data dilakuka dengan menggunakan rerata uji t satu sisi ( independent sample $t$ test) dan analisis regresi berganda (Ordinary least square). Hasil penelitian menunjukkan bahwa (1) pangsa pengeluaran pangan rumah tangga tani di daerah perkotaan lebih rendah dari pangsa pengeluaran pangan rumah tangga tani di daerah perdesaan (2) kecukupan energi rumah tangga tani di daerah perkotaan tidak lebih tinggi jika dibandingkan dengan rumah tangga tani di daerah perdesaan (3) rumah tangga di daerah perkotaan tahan pangan $20 \%$, rentan pangan $40 \%$, kurang pangan $12 \%$, rawan pangan $28 \%$. Rumah tangga di daerah perdesaan tahan pangan $16 \%$, rentan pangan $48 \%$, kurang pangan $4 \%$, rawan pangan $32 \%$ (4) pola pangan harapan rumah tangga tani di daerah perkotaan tidak lebih tinggi jika dibandingkan dengan pola pangan harapan di daerah perdesaan (5) faktor-faktor yang berpengaruh secara positif terhadap ketahanan pangan rumah tangga tani adalah pendapatan rumah tangga tani, serta lokasi (perkotaan dan perdesaan).

Kata kunci: Pangsa pengeluaran pangan, kecukupan energi, ketahanan pangan, perkotaan dan perdesaan.

\section{PENDAHULUAN}

Berdasarkan UU Pangan no 18 tahun 2012 pangan merupakan segala sesuatu yang berasal dari sumber hayati produk pertanian, perkebunan, kehutanan, perikanan, peternakan, perairan, dan air, baik yang diolah maupun tidak diolah yang diperuntukkan sebagai makanan atau minuman bagi konsumsi manusia, termasuk bahan tambahan pangan, bahan baku pangan, dan bahan lainnya yang digunakan dalam proses penyiapan, pengolahan, dan atau pembuatan makanan atau minuman.

Definisi ketahanan pangan berdasarkan UU Pangan no 18 tahun 2012 menjelaskan bahwa ketahanan pangan merupakan kondisi terpenuhinya pangan bagi Negara sampai dengan perseorangan, yang tercermin dari tersedianya pangan yang 
cukup, baik jumlah maupun mutunya, aman, beragam, bergizi, merata dan terjangkau serta tidak bertentangan dengan agama, keyakinan, budaya masyarakat untuk dapat hidup sehat, aktif, dan produktif secara berkelanjutan.

Ketahanan pangan merupakan suatu sistem yang terdiri atas subsistem ketersediaan dan distribusi pangan serta subsistem konsumsi. Ketersediaan dan distribusi memfasilitasi pasokan pangan yang stabil dan merata ke seluruh wilayah, sedangkan subsistem konsumsi memungkinkan setiap rumah tangga memperoleh pangan yang cukup dan memanfaatkannya secara bertanggungjawab untuk memenuhi kebutuhan gizi setiap anggota keluarga. Ketahanan pangan merupakan isu yang berada di tingkat wilayah hingga tingkat keluarga. Terdapat dua elemen penting yaitu ketersediaan pangan dan akses setiap individu terhadap pangan yang cukup (Suryana, 2004).

Terdapat suatu kendala dalam pemenuhan pangan bagi setiap anggota rumah tangga baik dalam aspek ketersediaan pangan maupun aspek konsumsi. Hal ini dapat terjadi karena pengaruh oleh beberapa faktor. Aspek ketersediaan pangan menjadi kendala bagi rumah tangga pada saat permintaan pangan tinggi, disamping itu produksi pangan bersifat lambat. Aspek konsumsi menjadi kendala rumah tangga ketika rumah tangga tidak mampu memenuhi kebutuhan gizi anggota rumah tangganya. Hal ini dapat terjadi karena adanya faktor kemampuan ekonomi rumah tangga (pendapatan dan pengeluaran), daya beli, perubahan selera. Berdasarkan Purwaningsih 2008 dalam Purwaningsih dkk (2010) menunjukkan bahwa pendapatan rumah tangga menentukan daya beli, dan daya beli ini mencerminkan keterjangkauan pangan atau aksesibilitas rumah tangga terhadap pangan. Semakin tinggi tingkat pendapatan rumah tangga maka menunjukkan daya beli yang tinggi, dan rumah tangga semakin mudah mengakses pangan.

Kecukupan gizi rumah tangga dapat dihitung dengan melihat nilai kecukupan energi yang berasal dari pangan yang dikonsumsi setiap hari oleh seseorang, kemudian dibandingkan nilainya berdasarkan anjuran angka kecukupan energi. Konsumsi yang dilakukan oleh rumah tangga berupa konsumsi pangan dan non pangan. Berdasarkan data tersebut dapat dianalisis nilai pangsa pengeluarannya. Adanya Perhitungan silang pangsa pengeluaran pangan dan kecukupan energi mampu menilai tingkat ketahanan pangan dari rumah tangga, khususnya rumah tangga tani. Kecukupan energi dapat juga digunakan untuk melihat ukuran susunan menu yang berfungsi untuk melihat komposisi dari keseimbangan gizi.

Perdesaan merupakan wilayah dimana mayoritas penduduk memiliki mata pencaharian sebagai petani untuk memenuhi kebutuhan rumah tangganya. Selain itu, karakteristik lain dari wilayah perdesaan adalah kepemilikan aset yang terbatas, sulitnya akses terhadap modal, serta kurangnya akses terhadap pasar. Akses terhadap pasar dapat mempermudah masyarakat dalam mendapatkan informasi serta membantu masyarakat dalam kegiatan jual beli. Kurangnya akses terhadap pasar akan menyebabkan produk yang dihasilkan kurang kompetitif sehingga pendapatan yang diperoleh rendah karena produksinya tidak efisien. Sedangkan rumah tangga di wilayah perkotaan memiliki mata pencaharian yang heterogen, termasuk di dalamnya sebagai seorang petani. Perkotaan merupakan wilayah dimana rumah tangga dapat dengan mudah untuk melakukan akses terhadap pasar. Hal ini dikarenakan wilayah perkotaan memiliki lokasi yang strategis. Perbedaan antara rumah tangga tani yang berada di wilayah perdesaan dengan rumah tangga tani yang terdapat di wilayah perkotaan tentu akan memberikan dampak yang berbeda untuk mengakses pangan.

Ketahanan pangan yang berada di tingkat rumah tangga dapat tercermin dari aspek distribusi dan konsumsi. Keadaan ini mampu memberikan gambaran tingkat ketahanan pangan secara nyata yang ada dalam kehidupan bermasyarakat, jika dibandingkan dengan ketahanan pangan yang berada di tingkat nasional. Ketahanan pangan rumah tangga tani merupakan hal yang menarik untuk dikaji. Hal ini dikarenakan sebagian besar penduduk Indonesia memiliki mata pencaharian sebagai seorang petani.

Berdasarkan Suparlan dkk dalam Hidayah (2011) perbandingan masyarakat perdesaan dan perkotaan dalam tabel 1.1.

Berdasarkan uraian yang telah dipaparkan, tingkat ketahanan pangan rumah tangga tani merupakan hal yang menarik untuk dikaji. Hal ini dikarenakan petani memiliki peran sebagai manajer dalam usahataninya, serta sebagai konsumen pangan. Penelitian ini akan menganalisis ketahanan 
Tabel 1.1 Perbandingan Masyarakat Perdesaan dan Perkotaan.

\begin{tabular}{|c|c|c|c|}
\hline No & Aspek & Perdesaan & Perkotaan \\
\hline 1 & Lingkungan fisik & $\begin{array}{l}\text { Didominasi pepohonan, udara masih segar, } \\
\text { fasilitas kurang lengkap. Pemukiman tidak } \\
\text { padat. }\end{array}$ & $\begin{array}{l}\text { Didominasi bangunan buatan, udara } \\
\text { berpolusi. Fasilitas fisik lebih lengkap. } \\
\text { Pemukiman padat dan sesak. }\end{array}$ \\
\hline 2 & Lingkungan sosial & $\begin{array}{l}\text { Kepadatan penduduk rendah, lapangan } \\
\text { kerja didominasi sektor pertanian. } \\
\text { Tingkat pendidikan lebih rendah. Tingkat } \\
\text { perekonomian dan gaya hidup relatif } \\
\text { homogen. Relasi sosial kuat. }\end{array}$ & $\begin{array}{l}\text { Kepadatan penduduk tinggi, lapangan } \\
\text { kerja didominasi sektor industri. Tingkat } \\
\text { pendidikan lebih tinggi. Tingkat } \\
\text { perekonomian dan gaya hidup heterogen. } \\
\text { Relasi sosial melemah. }\end{array}$ \\
\hline 3 & Nilai hidup & $\begin{array}{l}\text { Berjuang untuk dapat bertahan hidup. Dapat } \\
\text { makan secara teratur sudah lumayan. }\end{array}$ & $\begin{array}{l}\text { Lebih memperhatikan kesehatan, } \\
\text { keamanan dan prestige. }\end{array}$ \\
\hline 4 & $\begin{array}{l}\text { Kecenderungan } \\
\text { diversifikasi makanan } \\
\text { pokok }\end{array}$ & $\begin{array}{l}\text { Relatif sering melakukan diversifikasi, namun } \\
\text { motivasi untuk melakukan diversifikasi } \\
\text { bersifat ekstrinsik (keadaan darurat saat } \\
\text { harga beras tidak terjangkau). }\end{array}$ & $\begin{array}{l}\text { Masih belum siap. Diversifikasi pangan } \\
\text { hanya sebagai pangan selingan atau saat } \\
\text { makan pagi. Seandainya siap, motivasinya } \\
\text { hanya karena bersifat intrinsik. }\end{array}$ \\
\hline
\end{tabular}

Sumber: Suparlan dkk dalam Hidayah (2011).

pangan rumah tangga tani yang terdapat di Gunungkidul. Hal ini dengan menggunakan pertimbangan bahwa Kabupaten Gunungkidul berdasarkan data BPS tahun 2012 memiliki luasan pertanian yang paling besar di Provinsi Yogyakarta yaitu sebesar 7.865 hektar lahan sawah serta sebesar 117.835 hektar lahan kering. Adanya perbedaan berdasarkan aspek lingkungan fisik, lingkungan sosial, nilai kehidupan, kecenderungan diversifikasi makanan pokok antara wilayah perdesaan dan perkotaan tentu akan memberikan perbedaan besarnya pendapatan serta konsumsi rumah tangga tani. Besarnya pendapatan yang dilakukan rumah tangga tani akan mempengaruhi konsumsi pangan dan non pangan yang dilakukan rumah tangga tani. Hal ini tentu akan berdampak pada tingkat ketahanan pangan rumah tangga tani. Berdasarkan latar belakang tersebut, rumah tangga tani yang terdapat di wilayah Gunungkidul menarik

\section{Dasar Teori}

\section{Ketahanan Pangan}

Ketahanan pangan merupakan suatu sistem yang terdiri atas subsistem ketersediaan dan distribusi pangan serta subsistem konsumsi. Ketersediaan dan distribusi memfasilitasi pasokan pangan yang stabil dan merata ke seluruh wilayah, sedangkan subsistem konsumsi memungkinkan setiap rumah tangga memperoleh pangan yang cukup dan memanfaatkannya secara bertanggungjawab untuk memenuhi kebutuhan gizi setiap anggota keluarga. Berdasarkan hal tersebut, ketahanan pangan merupakan isu yang berada di tingkat wilayah- wilayah hingga tingkat keluarga. Terdapat dua elemen penting yaitu ketersediaan pangan dan akses setiap individu terhadap pangan yang cukup (Suryana, 2004).

Berdasarkan Undang- Undang Pangan no 18 tahun 2012 ketahanan pangan merupakan kondisi terpenuhinya pangan bagi negara sampai dengan perseorangan untuk diteliti bagaimanakah pangsa pengeluaran pangan, bagaimanakah tingkat kebutuhan energi, tingkat ketahanan pangan rumah tangga, pola pangan harapan. Serta faktor faktor yang mempengaruhi pangsa pengeluaran pangan. yang tercermin dari tersedianya pangan yang cukup, baik jumlah maupun mutunya, aman, beragam, bergizi, merata, dan terjangkau serta tidak bertentangan dengan agama, keyakinan, dan budaya masyarakat.

Konsep ketahanan pangan (food security) sebenarnya lebih luas jika dibandingkan dengan konsep swasembada pangan dan bahkan kemandirian pangan sekalipun. Beberapa ahli sepakat bahwa ketahanan pangan minimal mengandung dua unsur pokok, yaitu ketersediaan pangan dan aksesibilitas pangan terhadap bahan pangan tersebut. Salah satu dari unsur tersebut tidak terpenuhi, maka suatu Negara belum dapat dikatakan mempunyai ketahanan pangan yang baik. Walaupun pangan tersedia di tingkat nasional dan di tingkat regional, tetapi jika akses individu untuk memenuhi kebutuhan pangannya tidak merata, maka ketahanan pangan masih dikatakan rapuh. Aspek distribusi bahan pangan sampai ke pelosok rumah tangga perdesaan yang tentunya mencangkup fungsi tempat, ruang dan waktu juga tidak kalah pentingnya dalam 
upaya memperkuat strategi ketahanan pangan (Arifin, 2004).

\section{Teori Konsumsi}

Konsumsi merupakan titik pangkal dan tujuan akhir seluruh kegiatan ekonomi masyarakat. Kalau produksi diartikan " menciptakan utility" dalam bentuk barang dan jasa yang dapat memenuhi kebutuhan manusia, maka konsumsi berarti memakai atau menggunakan utility untuk memenuhi kebutuhan (Gilarso, 1993). Utilitas menunjukkan kepuasan. Secara lebih tepat, konsep ini mengacu pada bagaimana konsumen mengurutkan (berdasarkan utilitas) barang-barang dan jasa-jasa yang berbeda. Utilitas merupakan suatu gagasan yang ilmiah yang digunakan para ekonom untuk memahami bagaimana konsumen yang rasional membagai sumber daya yang terbatas diantara komoditas-komoditas yang memberikan mereka kepuasan (Samuelson dan Nordhanus, 2003).

Pokok persoalan yang dihadapi oleh setiap orang dan setiap keluarga adalah orang ingin hidup layak sebagai manusia dan sebagai warga masyarakat. Berdasarkan hal tersebut dibutuhkan bermacam-macam barang dan jasa seperti makanan, pakaian, rumah, obat, sepatu, radio, pengangkutan. Hal ini didapatkan dengan tidak gratis, melainkan harus dibeli, karena harus diproduksi terlebih dahulu karena untuk dapat membeli semuanya itu diperlukan uang, sebab kita harus membayar harganya. Jadi, seorang konsumen atau suatu keluarga di satu pihak berhadapan dengan kebutuhan-kebutuhan hidup

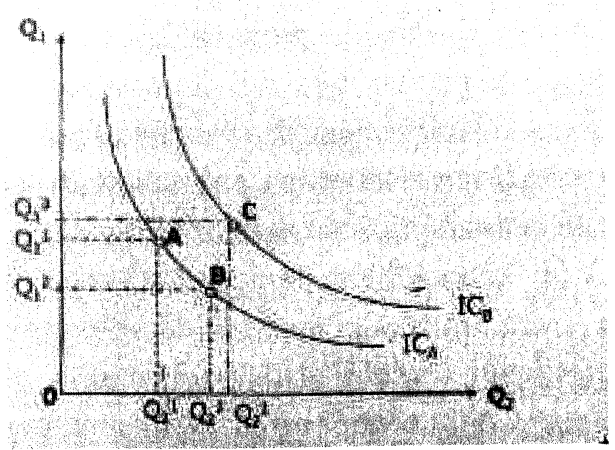

Gambar 1.1 Kurva Indiferen Konsumen Sumber: Samuelson dan Nordhanus, 2003

Keterangan :

ICA $=$ kurva indiferen

$\mathrm{A} \mathrm{ICB}=$ Kurva indiferen

$\mathrm{B}$ Q1 = Jenis barang ke 1

$\mathrm{Q} 2=$ jenis barang $\mathrm{ke} 2$ yang harus dipenuhi, dan harus mampu menentukan barang apa yang harus dibeli yang disesuaikan dengan pendapatannya (Gilarso, 1993).

Kurva indiferen merupakan kurva yang menggambarkan kombinasi dari barang yang mampu memberikan kepuasan yang sama pada rumah tangga. Titik A, B, C merupakan kombinasi (Q1) dan (Q2) yang dikonsumsi oleh rumah tangga, semakin jauh titik tersebut dari titik origin maka kepuasan konsumen akan semakin tinggi.

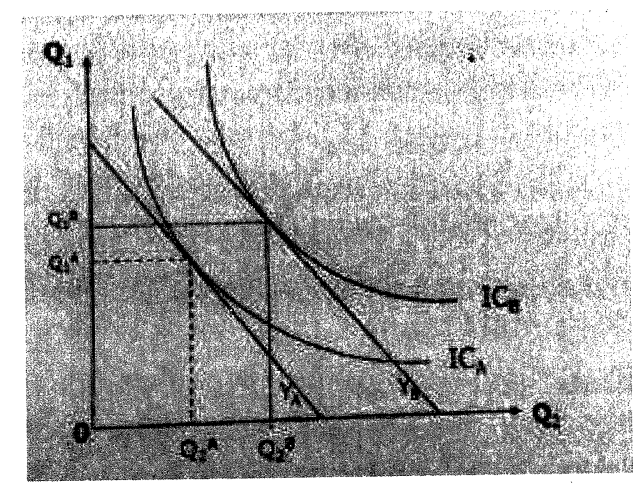

Gambar 1.2 Kurva Indiferen dan kesetimbangan Sumber: Lipsey et. al. 1991

Keterangan :

$\mathrm{IC}_{\mathrm{A}}=$ kurva indiferen $\mathrm{A}$

$\mathrm{IC}_{\mathrm{B}}=$ Kurva indiferen $\mathrm{B}$

$\mathrm{Q} 1=$ Jenis barang ke 1

$\mathrm{Q} 2=$ jenis barang $\mathrm{ke} 2$

$\mathrm{YA}_{\mathrm{A}}=$ Garis Anggaran A

$\mathrm{YB}=$ Garis Anggaran $\mathrm{B}$

Ekuilibrium konsumen akan didapatkan pada saat garis anggaran bersinggungan dengan kurva indiferen. Hal ini akan mengakibatkan rasio substitusi konsumen sama persis dengan slope garis anggaran. Berdasarkan gambar 1.2 terlihat bahwa apabila konsumen memiliki suatu pendapatan uang tetap, seluruhnya dibelanjakan (Q1) dan (Q2) maka konsumen akan terkendala untuk bergerak di sepanjang garis anggaran. Konsumen akan bergerak disepanjang garis anggaran hingga bersinggungan dengan kurva indiferen.

\section{Teori Permintaan}

Permintaan adalah banyaknya jumlah barang yang diminta pada suatu pasar tertentu dengan tingkat harga tertentu pada tingkat pendapatan tertentu dan dalam periode tertentu. Terdapat beberapa faktor yang dapat mempengaruhi permintaan dari seorang individu atau masyarakat terhadap suatu barang (Putong, 2003). 


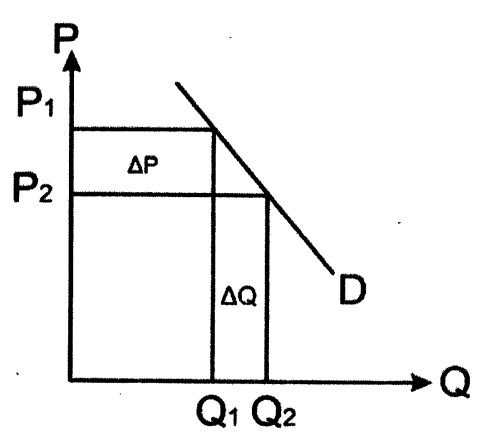

Gambar 1.3 Kurva Permintaan

Keterangan :

$\mathrm{P}_{1}=$ Harga barang ke 1

$\mathrm{P}_{2}=$ Harga barang ke 2

$\mathrm{Q} 1=$ Jumalah barang yang diminta 1

Q2 = Jumalah barang yang diminta 2

$\mathrm{D}=$ Kurva permintaan

Sumber: Samuelson and Nordhanus, 2003.

Gambar tersebut merupakan gambar dari kurva permintaan. Berdasarkan hukum permintaan diketahui apabila harga suatu komoditi mengalami kenaikan maka jumlah barang yang diminta akan barang tersebut semakin sedikit. Berdasarkan gambar 1.3 terlihat bahwa mula-mula harga barang adalah $P_{1}$ dengan kuantitas yang diminta sebanyak Q1. ketika terjadi penurunan harga barang menjadi $\mathrm{P}_{2}$, maka jumlah barang yang diminta akan semakin naik menjadi sebesar Q2.

Berdasarkan Samuelson

dan Nordhanus (2003), terdapat beberapa faktor yang mempengaruhi banyak barang yang diminta pada tingkat harga tertentu. Hal tersebut adalah pendapatan rata-rata, jumlah penduduk, harga dan ketersediaan barang yang berkaitan, selera. Apabila pendapatan rata-rata konsumen naik maka individu akan cenderung membeli barang dalam jumlah yang banyak. Semakin banyak jumlah penduduk maka akan mengakibatkan permintaan akan suatu barang semakin tinggi. Selera masyarakat memiliki pengaruh yang besar terhadap keinginan masyarakat untuk membeli suatu barang.

\section{Metode Penilaian Katahanan Pangan}

Konsep pengukuran ketahanan pangan dapat dilakukan dengan menggunakan berbagai macam metode, berikut adalah berbagai metode untuk menilai tingkat ketahanan pangan yang terdapat di rumah tangga :

a. Pengukuran ketahanan pangan dapat dilakukan dengan menggunakan tingkat kecukupan konsumsi energi (TKE). Suatu rumah tangga disebut tahan pangan jika tingkat kecukupan energi $\geq 70 \%$, dan jika rumah tangga memiliki tingkat kecukupan energi sebesar $<70 \%$ disebut tidak tahan pangan. Pengukuran dengan menggunakan metode ini dilakukan oleh Suhardianto (2008).

b. Menggunakan indikator silang antara kecukupan energi dengan pangsa pengeluaran pangan atau sering dikenal dengan metode Jonsson and Toole.

Metode Jonnson and Toole telah dilakukan dalam penelitian yang dilakukan oleh Rahmi (2013), Purwaningsih dkk (2010), Safitri (2012).

c. Metode untuk menilai ketahanan pangan dapat juga dilakukan dengan menggunakan Indeks Porsi Pengeluaran Pangan, Indeks Angka Kecukupan Energi dan Indeks Angka Kecukupan Protein. Rumah Tangga dikatakan tahan pangan jika nilai indeks ketahanan pangan lebih dari 1, dan kurang tahan pangan jika nilai indeks ketahanan pangan kurang dari 1. Penelitian dengan menggunakan metode ini dilakukan oleh Purwanti (2008).

\section{METODE PENELITIAN}

Berdasarkan Whitney 1960 dalam Nazir 2011 metode deskriptif merupakan suatu metode dalam meneliti status kelompok manusia, suatu objek, suatu set kondisi, suatu sistem pemikiran, ataupun suatu kelas peristiwa pada masa sekarang. Tujuan dari penelitian deskriptif adalah untuk membuat deskripsi, gambaran atau lukisan secara sistematis,

Tabel 1.2 Metode Penilaian Ketahanan Pangan

\begin{tabular}{clll}
\hline \multirow{2}{*}{$\begin{array}{c}\text { konsumsi energi per unit ekuivalen } \\
\text { dewasa }\end{array}$} & \multicolumn{3}{c}{ Pangsa pengeluaran pangan } \\
& Rengeluaran & \\
& Rendah $(<60 \%$ total $)$ & pengeluaran & Tinggi $(\geq 60 \%$ total $)$ \\
\hline Cukup $(>80 \%$ kecukupan energi $)$ & Tahan pangan & Rentan Pangan \\
Kurang $(\leq 80 \%$ kecukupan energi) & Kurang pangan & Rawan pangan \\
\hline
\end{tabular}

Sumber: Jonsson and Toole 1991 dalam Maxwell et. al. tahun 1999 
faktual dan akurat mengenai fakta- fakta, sifat- sifat serta hubungan antarfenomena yang diselidiki.

\section{Analisis Independent t- test}

a. Diduga pangsa pengeluaran pangan rumah tangga tani di perkotaan lebih rendah daripada pangsa pengeluaran pangan rumah tangga tani di perdesaan.

b. Diduga tingkat kecukupan energi rumah tangga tani di perkotaan lebih tinggi daripada kecukupan energi rumah tangga tani perdesaan.

c. Diduga tingkat ketahanan pangan rumah tangga tani di perkotaan lebih tinggi daripada ketahanan pangan rumah tangga tani di wilayah perdesaan.

d. Diduga pola pangan harapan rumah tangga tani di perkotaan lebih tinggi jika dibandingkan dengan pola pangan harapan rumah tangga tani di perdesaan.

e. Diduga faktor- faktor yang mempengaruhi ketahanan pangan rumah tangga tani di adalah pendapatan rumah tangga tani, pendidikan kepala rumah tangga, jumlah anggota rumah tangga, harga beras, harga tempe, harga telur, harga daging, daerah perkotaan dan perdesaan.

$\mathrm{LnY}=\alpha+\beta 1 \ln \mathrm{X}_{1}+\beta 2 \ln \mathrm{X}_{2}+\beta 3 \ln \mathrm{X}_{3}+\beta 4 \ln$ $\mathrm{X}_{4}+\beta 5 \ln \mathrm{X}_{5}+\beta 6 \ln \mathrm{X}_{6}+\beta 7 \ln \mathrm{X}_{7} \mu+\mathrm{dD}_{1}+\mu$

\section{Keterangan}

$\mathrm{Y}=$ Ketahanan pangan rumah tangga tani

$\alpha \quad=$ intercept

$\beta 1-\beta 5=$ koefisien regresi

$\mathrm{X}_{1}=$ pendapatan rumah tangga tani ( $\mathrm{Rp} /$ tahun)

$\mathrm{X}_{2}=$ pendidikan kepala rumah tangga (tahun)

$\mathrm{X}_{3}=$ jumlah anggota rumah tangga (jiwa)

$\mathrm{X} 4=$ Harga beras $(\mathrm{Rp} / \mathrm{Kg})$

$\mathrm{X}_{5}=$ Harga tempe $(\mathrm{Rp} /$ potong)

$\mathrm{X}_{6}$ = Harga telur $(\mathrm{Rp} / \mathrm{Kg})$

$\mathrm{X}_{7}=$ Harga daging $(\mathrm{Rp} / \mathrm{Kg})$

$\mathrm{D} 1=$ Dummy perkotaan dan Perdesaan (Perkotaan 1, Perdesaan 0)

\section{Pengujian Model}

Pengujian dilakukan dengan menggunakan uji independent t- test ( hipotesis 1-4), sedangkan hipotesis 5 dilakukan untuk mengetahui pengaruh faktor yang mempengaruhi ketahanan pangan adalah dengan menggunakan metode ordinary least square (OLS). Hal yang harus dilakukan pertama kali untuk memberikan pendugaan yang baik dan tidak bias adalah melakukan uji penyimpangan asumsi klasik yang terdiri dari uji normalitas, uji autokorelasi, uji multikolinearitas, uji heteroskedastisitas. Setelah dilakukan uji asumsi klasik dilakukan analisis regresi linear berganda terhadap faktor-faktor yang mempengaruhi ketahanan pangan

\section{HASIL DAN PEMBAHASAN}

Tabel 1.3 Uji t Pangsa Pengeluaran Pangan Perkotaan dan Perdesaan Uraian

\begin{tabular}{lccc}
\hline \multirow{2}{*}{ Uraian } & \multicolumn{2}{c}{ Nilai } \\
\cline { 2 - 4 } & Perkotaan & Perdesaan \\
\hline Rerata Pangsa & 62,69 & 70,51 \\
Pengeluaran Pangan & & 13,83 \\
Standar Deviasi (Sd) & 13,83 & & \\
t hitung & & 1,99 & \\
$\mathrm{t}$ tabel & \multicolumn{3}{c}{1,67} \\
Sig t (one tail) & \multicolumn{3}{c}{0,02} \\
\hline
\end{tabular}

Sumber : Analisis Data Primer, 2013

Berdasarkan tabel 1.3 mengenai uji t satu sisi pangsa pengeluaran pangan rumah tangga tani daerah perkotaan dan perdesaan diperoleh nilai $(p<0,05)$ sehingga dapat disimpulkan bahwa $\mathrm{H}_{0}$ ditolak yang menunjukkan bahwa pangsa pengeluaran pangan rumah tangga tani di daerah perkotaan lebih rendah jika dibandingkan dengan pangsa pengeluaran pangan rumah tangga tani di daerah perdesaan.

Tabel 1.4 Uji t Angka Kecukupan Energi Perkotaan dan Perdesaan

\begin{tabular}{|c|c|c|}
\hline \multirow{2}{*}{ Uraian } & \multicolumn{2}{|c|}{ Nilai } \\
\hline & Perkotaan & Perdesaan \\
\hline $\begin{array}{l}\text { Rerata Kecukupan } \\
\text { energi }\end{array}$ & $1.964,82$ & $2.141,75$ \\
\hline Standar Deviasi (Sd) & 751,35 & $1,197,74$ \\
\hline t hitung & & \\
\hline $\mathrm{t}$ tabel & & \\
\hline Sig t (one tail) & & \\
\hline
\end{tabular}

Sumber: Analisis Data Primer, 2013.

Berdasarkan tabel 1.4 dapat diketahui uji $\mathrm{t}$ satu sisi angka kecukupan energi daerah perkotaan dan perdesaan, diperoleh hasil $(p>0,05)$ hal ini menunjukkan bahwa $\mathrm{H}_{0}$ diterima. Berdasarkan hasil penelitian ini menunjukkan kecukupan energi rumah tangga tani di daerah perkotaan tidak lebih besar atau sama dengan tingkat kecukupan energi di daerah perdesaan. 
Tabel 1.5 Distribusi Rumah Tangga Tani di Daerah Perkotaan dan Perdesaan Kabupaten Gunungkidul Berdasarkan Tingkat Ketahanan Pangan

\begin{tabular}{|c|c|c|c|c|c|}
\hline \multirow{2}{*}{ No } & \multirow{2}{*}{ Tingkat Ketahanan Pangan } & \multicolumn{2}{|c|}{ Jumlah Rumah Tangga } & \multicolumn{2}{|c|}{ Rerata (Persentase) } \\
\hline & & Perkotaan & Perdesaan & Perkotaan & Perdesaan \\
\hline 1 & Tahan Pangan & 5 & 4 & 20 & 16 \\
\hline 2 & Rentan Pangan & 10 & 12 & 40 & 48 \\
\hline 3 & Kurang Pangan & 3 & 1 & 12 & 4 \\
\hline 4 & Rawan Pangan & 7 & 8 & 28 & 32 \\
\hline & Total & 25 & 25 & 100 & 100 \\
\hline
\end{tabular}

Sumber: Analisis Data Primer, 2013.

Berdasarkan tabel 1.5 dapat diketahui distribusi rumah tangga tani daerah perkotaan dan perdesaan di Kabupaten Gunungkidul berdasarkan tingkat ketahanan pangan. Pengukuran ketahanan pangan dilakukan dengan menggunakan kombinasi silang antara pangsa pengeluaran pangan serta kecukupan energi rumah tangga.

Tingkat ketahanan pangan dibagi menjadi empat kategori yaitu tahan pangan, rentan pangan, kurang pangan, serta rawan pangan.

Berdasarkan data, dapat dilihat rumah tangga tahan pangan di perkotaan sebesar $20 \%$, sedangkan di daerah perdesaan sebesar $16 \%$. Rumah tangga dikatakan tahan pangan apabila memiliki nilai pangsa pengeluaran pangan yang rendah yaitu $<60$ $\%$ dari total pengeluaran, serta konsumsi energi $>80 \%$ dari anjuran angka kecukupan energi. Berdasarkan pengamatan yang terdapat di lapangan daerah perkotaan memiliki jumlah rumah tangga tahan pangan yang lebih banyak jika dibandingakan dengan rumah tangga perdesaan karena rumah tangga tersebut banyak melakukan konsumsi non pangan. Rendahnya konsumsi non pangan dikarenakan rumah tangga di daerah perkotaan banyak yang memiliki mata pencaharian sebagai seorang petani. Selain itu, tingkatan pendapatan rumah tangga juga akan memepengaruhi kemampuan suatu rumah tangga untuk mengakses pangan. Berdasarkan Purwaningsih (2010) pendapatan akan menentukan daya beli dalam masyarakat, dimana daya beli akan mempengaruhi keterjangkauan pangan. Semakin tinggi pendapatan suatu rumah tangga maka daya beli rumah tangga tersebut juga akan tinggi dan semakin mudah dalam mengakses pangan. Berdasarkan hal tersebut, terlihat bahwa rumah tangga di daerah perkotaan lebih mudah dalam mengakses pangan, sehingga jumlah rumah tangga tahan pangan di daerah perkotaan lebih banyak jika dibandingkan dengan rumah tangga tahan pangan di daerah perdesaan.
Rumah tangga dikatakan rentan pangan apabila pangsa pengeluaran pangan $\geq 60 \%$ dari pengeluaran total sedangkan konsumsi energi sebesar $>80 \%$ dari kecukupan energi. Jumlah rumah tangga rentan pangan di daerah perkotaan sebanyak 10 rumah tangga, sedangkan di daerah perdesaan sebanyak 12 rumah tangga. Berdasarkan pengamatan di lapangan jumlah rumah tangga rentan banyak di temukan di daerah perdesaan karena pangsa pengeluaran pangan rumah tangga daerah perdesaan lebih tinggi jika dibandingakan dengan pangsa pengeluaran pangan di daerah perkotaan. Jumlah rumah tangga rentan pangan di daerah perdesaan lebih banyak jika dibandingkan dengan rumah tangga di daerah perkotaan. Hal ini menunjukkan rendahnya pendapatan yang diterima oleh rumah tangga di daerah perdesaan. Berdasarkan keadaan ini, seharusnya pemerintah memberikan peluang kerja yang banyak sehingga mampu meningkatkan pendapatan rumah tangga di daerah perdesaan.

Kategori tingkat ketahanan pangan dengan pangsa pengeluaran pangan sebesar $\geq 60 \%$ dan kecukupan energi sebesar $\leq 80 \%$ disebut rawan pangan. Di daerah perkotaan jumlah rumah tangga rawan pangan sebanyak 7 rumah tangga atau setara dengan $28 \%$ dari total rumah tangga yang terdapat di daerah perkotaan, sedangkan di daerah perdesaan jumlah rumah tangga rawan pangan sebanyak 8 rumah tangga atau setara dengan $32 \%$ dari total rumah tangga yang terdapat di daerah perdesaan. Rumah tangga rawan pangan di daerah perdesan lebih banyak jika dibandingkan dengan rumah tangga rawan pangan di daerah perkotaan. Rumah tangga rawan pangan berarti rumah tangga tersebut memiliki pendapatan yang rendah serta serta tidak mampu untuk mencukupi kebutuhan energinya. Upaya yang perlu dilakukan agar rumah tangga rawan pangan mampu mencukupi kebutuhan energi serta serta mampu untuk mengurangi pangsa 
pengeluaran pangan adalah dengan meningkatkan pendapatan rumah tangga di daerah penduduk rawan, diharapkan melalui hal ini kelompok rumah tangga rawan pangan mampu untuk mencaai keadaan tahan pangan.

Tabel 1.6 Uji t Pola Pangan Harapan Rumah Tangga Tani Perkotaan dan Perdesaan Kabupaten Gunungkidul

\begin{tabular}{lccc} 
& \multicolumn{2}{c}{ Uraian } & \\
& Perkotaan & Perdesaan \\
\hline Rerata Skor PPH & 52,07 & & 47,64 \\
Standar Deviasi (Sd) & 12,98 & & 15,71 \\
$\mathrm{t}$ hitung & & 1,08 & \\
$\mathrm{t}$ tabel & & 1,67 & \\
Sig t (one tail) & \multicolumn{3}{c}{0,14} \\
\hline
\end{tabular}

Sumber : Analisis Data Primer, 2013.

Berdasarkan tabel 1.6 mengenai uji t pola pangan harapan rumah tangga tani di perkotaan dan perdesaan diperoleh nilai $(\mathrm{P}>0,05)$. Hal ini berarti $\mathrm{H}_{0}$ diterima, sehingga pola pangan harapan di daerah perkotaan tidak lebih tinggi atau sama dengan pola pangan harapan di daerah perdesaan. Apabila dilihat berdasarkan reratanya nilai pph di daerah perkotaan lebih tinggi jika dibandingkan dengan nilai pph di daerah perdesaan, tetapi nilai standar deviasi yang ada di daerah perkotaan lebih rendah jika dibandingkan dengan standar deviasi di daerah perdesaan. Hal ini menunjukkan banyaknya variasi di daerah perdesaan.

\section{Konstanta}

Hasil analisis menunjukkan bahwa konstanta sebesar 12,194 artinya apabila variabel independen lainnya tidak ada atau dianggap memiliki nilai nol maka besarnya pangsa pengeluaran pangan sebesar $\ln 12,194$. Berdasarkan analisis regresi didapatkan nilai signifikansi $(p<0,05)$ hal ini menunjukkan bahwa konstanta berpengaruh terhadap pangsa pengeluaran pangan.

\section{Pendapatan rumah tangga tani}

Berdasarkan tabel 1.7 diketahui bahwa pendapatan secara signifikan dapat memberikan pengaruh terhadap ketahanan pangan rumah tangga tani. Nilai signifikansi yang diperoleh $(\mathrm{p}<0,01)$. Berdasarkan tabel 1.7 dapat pula diketahui koefisien variabel pendapatan sebesar 0,558 dengan expected sign negatif. Hal ini menunjukkan bahwa pendapatan memiliki hubungan yang berkebalikan/ korelasi negatif dengan pangsa pengeluaran pangan. Apabila terdapat peningkatan pendapatan sebesar $1 \%$ maka akan menurunkan pangsa pengeluaran pangan rumah tangga tani sebesar $0,558 \%$.

Hal ini menunjukkan bahwa semakin tinggi pendapatan seseorang maka pangsa pengeluaran pangan rumah tangga akan semakin kecil. Pangsa pengeluaran pangan memiliki hubungan terbalik dengan tingkat ketahanan pangan. apabila suatu rumah tangga memiliki pangsa pengeluaran pangan

Tabel 1.7 Hasil Analisis Regresi Linear Berganda Faktor- Faktor Yang Mempengaruhi Ketahanan Pangan Rumah Tangga Tani

\begin{tabular}{|c|c|c|c|c|}
\hline Variabel Independen & Expected Sign & Koefisien & thitung & Signifikan $\mathrm{t}$ \\
\hline Konstanta & + & 12,194 & 2,051 & $0,047^{* *}$ \\
\hline Ln Pendapatan rumah tangga tani $\left(\ln \mathrm{X}_{1}\right)$ & - & 0,558 & $-8,716$ & $0,000 * * *$ \\
\hline Ln Pendidikan Kepala Rumah Tangga Tani $\left(\ln \mathrm{X}_{2}\right)$ & - & 0,042 & $-0,636$ & 0,528 \\
\hline Ln Jumlah Anggota Rumah Tangga Tani $\left(\ln \mathrm{X}_{3}\right)$ & - & 0,003 & $-0,060$ & 0,952 \\
\hline Ln Harga Beras $\left(\ln \mathrm{X}_{4}\right)$ & + & 0,251 & 0,590 & 0,558 \\
\hline Ln Harga Tempe $\left(\ln \mathrm{X}_{5}\right)$ & - & 0,023 & $-0,170$ & 0,866 \\
\hline Ln Harga Telur $\left(\ln \mathrm{X}_{6}\right)$ & + & 0,211 & 1,480 & 0,147 \\
\hline Ln Harga Daging Ayam $\left(\ln X_{7}\right)$ & - & 0,233 & $-0,596$ & 0,554 \\
\hline Daerah Perkotaan dan perdesaan (Dummy) ( $\left.\mathrm{X}_{8}\right)$ & + & 0,084 & 1,838 & $0,073 *$ \\
\hline Adjusted R & & & & 0,667 \\
\hline F hitung & & & & 13,292 \\
\hline F signifikansi & & & & 0,000 \\
\hline
\end{tabular}

Sumber: Analisis Data Primer, 2014

Keterangan :

$* * *$ = signifikan pada $\alpha=0,01$

** = signifikan pada $\alpha=0,05$

* = signifikan pada $\alpha=0,10$

ns $=$ tidak signifikan 
yang rendah $(<60 \%)$ maka tingkat ketahanan pangan rumah tangga tersebut akan semakin tinggi. Sehingga, untuk meningkatkan ketahanan pangan rumah tangga harus dilakukan upaya meningkatkan pendapatan rumah tangga.

\section{Pendidikan Kepala rumah tangga}

Tingkatan pendidikan kepala rumah tangga tani berdasarkan penelitian tidak memberikan pengaruh secara signifikan terhadap ketahanan pangan rumah tangga tani $(\mathrm{p}>0,05)$. Pendidikan tidak berpengaruh terhadap pangsa pengeluaran pangan rumah tangga dikarenakan rumah tangga yang terdapat di Gunungkidul lebih banyak mengkonsumsi sumber pangan yang menjadi selera mereka yang berasal dari padi atau kacangkacangan.

\section{Jumlah anggota rumah tangga}

Berdasarkan tabel 1.7 menunjukkan bahwa jumlah anggota rumah tangga secara individual tidak memberikan pengaruh terhadap ketahanan pangan rumah tangga tani $(p>0,05)$. Berdasarkan teori, kenaikan jumlah penduduk akan menggeser permintaan ke arah kanan yang berarti akan lebih banyak komoditi yang di beli pada setiap tingkat harga. Pengamatan yang terjadi di lapangan jumlah anggota rumah tangga tidak akan mempengaruhi peningkatan permintaan akan suatu barang. Hal ini dikarenakan peningkatan jumlah penduduk belum mampu menciptakan permintaan baru. Hal ini dikarenakan penduduk belum memasuki usia kerja sehingga masih menjadi tanggungan oleh penduduk usia produktif.

\section{Harga beras}

Berdasarkan tabel 1.7 harga beras secara individu tidak memberikan pengaruh terhadap ketahanan pangan rumah tangga. Hal ini dikarenakan nilai $(p>0,1)$. Berdasarkan teori permintaan, apabila harga suatu barang naik maka akan menyebabkan permintaan akan suatu barang menurun. Hasil regresi menyatakan bahwa harga beras tidak berpengaruh terhadap ketahanan pangan. Hal ini dikarenakan beras merupakan makanan pokok yang dikonsumsi oleh masyarakat, oleh sebab itu fluktuasi harga beras tidak mempengaruhi permintaan akan beras.

\section{Harga tempe}

Berdasarkan tabel 1.7 harga tempe secara individu tidak memberikan pengaruh terhadap ketahanan pangan rumah tangga. Hal ini dikarenakan nilai $(p>0,1)$.

Berdasarkan teori permintaan, apabila harga suatu barang naik maka akan menyebabkan permintaan suatu barang menurun. Hasil regresi menyatakan bahwa harga tempe tidak berpengaruh terhadap pangsa pengeluaran pangan. Hal ini dikarenakan tempe merupakan lauk favorit yang digunakan sebagai sumber makanan yang mengandung banyak protein nabati dan banyak dikonsumsi oleh rumah tangga yang terdapat di Gunungkidul untuk memenuhi kebutuhan makanan sumber protein. Atau dapat dikatakan rumah tangga yang terdapat di Gunungkidul memiliki selera yang tinggi untuk mengkonsumsi tempe, sehingga harga tempe tidak berpengaruh terhadap permintaan akan tempe.

\section{Harga telur}

Berdasarkan tabel 1.7 harga telur secara individu tidak memberikan pengaruh terhadap pangsa pengeluaran pangan rumah tangga. Hal ini dikarenakan $(\mathrm{P}>0,1)$. Berdasarkan teori permintaan apabila harga suatu barang naik maka permintaan akan suatu barang atau jasa akan semakin menurun. Pengamatan yang terjadi di lapangan rumah tangga yang terdapat di daerah Gunungkidul lebih menggemari lauk yang berasal dari sumber protein nabati dari pada protein hewani. Hal ini mengakibatkan harga telur tidak signifikan terhadap pangsa pengeluaran pangan.

\section{Harga daging ayam}

Berdasarkan tabel 1.7 harga daging ayam secara individu tidak memberikan pengaruh terhadap ketahanan pangan rumah tangga. Hal ini dikarenakan nilai dari $(P>0,1)$. Berdasarkan pengamatan yang terjadi di lapangan, rumah tangga yang terdapat di daerah Gunungkidul lebih banyak mengkonsumsi bahan makanan yang terbuat dari sumber kacang- kacangan yang digunakan sebagai lauk dari pada yang berasal dari daging.

\section{Daerah Perkotaan dan Perdesaan}

Daerah perkotaan serta daerah perdesaan (dummy) diperoleh nilai $(p<0,1)$. Hal ini 
menunjukkan bahwa variabel lokasi yaitu daerah perkotaan dan perdesaan secara individu berpengaruh terhadap ketahanan pangan. Berdasarkan teori, pangsa pengeluaran pangan yang terdapat di daerah perdesaan lebih besar jika dibandingkan dengan pangsa pengeluaran pangan di perkotaan. Apabila suatu daerah memiliki pangsa pengeluaran pangan yang tinggi $>60 \%$ maka dikatakan rumah tangga tersebut tidak tahan pangan. Hal ini dikarenakan alokasi yang dikeluarkan rumah tangga untuk mengkonsumsi pangan lebih besar jika dibandingkan dengan alokasi non pangan. Apabila rumah tangga memiliki pangsa pengeluaran pangan yang rendah $\leq 60 \%$ maka rumah tangga memiliki ketahanan pangan yang tinggi.

\section{KESIMPULAN}

1. Pangsa pengeluaran pangan rumah tangga tani di daerah perkotaan lebih rendah dari pada pangsa pengeluaran pangan rumah tangga di daerah perdesaan.

2. Tingkat kecukupan energi rumah tangga tani yang berada di daerah perkotaan tidak lebih tinggi jika dibandingkan dengan tingkat kecukupan energi rumah tangga tani yang berada di perdesaan.

3. Ketahanan pangan rumah tangga tani kabupaten Gunungkidul di perkotaan diperoleh rumah tangga tahan pangan $20 \%$, rentan pangan $40 \%$, kurang pangan $12 \%$, rawan pangan $28 \%$. Daerah perdesaan rumah tangga tahan pangan $16 \%$, rentan pangan $48 \%$, kurang pangan $4 \%$, rawan pangan $32 \%$.

4. Pola pangan harapan rumah tangga tani di daerah perkotaan tidak lebih tinggi atau sama dengan pola pangan harapan di daerah perdesaan.

5. Faktor yang berpengaruh terhadap ketahanan pangan rumah tangga tani adalah pendapatan rumah tangga tani serta lokasi (perkotaan dan perdesaan).

\section{DAFTAR PUSTAKA}

Anonim, 2012. Undang- Undang Republik Indonesia Tahun 2012 Tentang Pangan. $<$ http://ppvt.setjen.deptan.go.id/ppvt pp/ files/61UU182012.pdf $>$. Diakses 6 Desember 2013.
Arifin, Bustanul. 2004. Penyediaan dan Aksesibilitas

Ketahanan Pangan dalam Prosiding Widyakarya Nasional Pangan dan Gizi viii. Jakarta.

Case, E. K., R.C. Fair. 2006. Prinsip- Prinsip Ekonomi. Erlangga. Jakarta.

Gilarso. 1993. Pengantar Ilmu Ekonomi Bagian Mikro Jilid 1. Kanisius. Yogyakarta.

Hidayah, Nurul. 2011. Kesiapan Psikologis Masyarakat Perdesaan Dan Perkotaan Menghadapi Diversifikasi Pangan Pokok. Jurnal Humanitas Vol VIII(1).

Lantarsih, R., Widodo, S., Darwanto, D.H., Lestari, S.B., Paramita,S. 2011. Sistem Ketahanan Pangan Nasional: Kontribusi Ketersediaan dan Konsumsi Energi Serta Optimalisasi Distribusi Beras. Analisis Kebijakan Pertanian Vol 9 no $1: 33-51$.

Lipsey, R.G., P.O.Steiner., D.D Purvis, P.N. Courant. 1991. Mikroekonomi. Binarupa Aksara. Jakarta.

Maxwell, D. Ahiadeke, C., Levin, C., Klemesu, A.M., Zakariah, S., Mary, L. 1999. Alternative Food Security Indicators: Revisting, The Frequency and Severity of Coping Strategies. Journal Food Policy (24): 411- 429.

Nazir, Moh. 2011. Metode Penelitian. Ghalia Indonesia. Bogor.

Purwaningsih, Y., Hartono, S. Masyhuri, Mulyo, J.H. 2010. Pola Pengeluaran Pangan Rumah Tangga Menurut Tingkat Ketahanan Pangan di Provinsi Jawa Tengah. Jurnal Ekonomi Pembangunan Vol 11 nomor 2 (236-253). Purwanti, Pudji. 2008. Simulasi Kebijakan Pengembangan Ekonomi dan Ketahanan Pangan Rumah Tangga Nelayan Kecil Di Jawa Timur. Universitas Brawijaya. Disertasi.

Purwantini, T.B., H.P.S. Rachman dan Y. Marisa. 2005. Analisis Ketahanan Pangan Regional dan Tingkat Rumah Tangga (Studi Kasus di Provinsi Sulawesi Utara) Dalam Penguatan Ketahanan Pangan Rumah Tangga dan Wilayah Sebagai Basis Keyahanan Pangan Nasional Series no 26 Pusat Analisis Sosieal Ekonomi dan Kebijakan Pertanian. Bogor. Putong, Iskandar. 2003. Pengantar Ekonomi Mikro dan Makro. Ghalia Indonesia. Jakarta 
Rahmi, R.D. 2013. Ketahanan Pangan Rumah Tangga Petani Di Kecamatan Ponjong Kabupaten Gunungkidul. Skripsi.

Safitri, D.A. 2012. Analisis Ketahanan Pangan Rumah Tangga Tani Di Wilayah Perdesaan dan Perkotaan Kabupaten Sleman. Skripsi.

Samuelson, P.A. dan Nordhanus, W.D. 2003. Ilmu Mikroekonomi. Mc Graw Hill Education PT Media Global Edukasi. Jakarta.
Suhardianto, Anang, Baliwati, Y.F., Sukandar, D. 2008. Ketahanan Pangan Rumah Tangga Petani Penghasil Beras Organik. Jurnal Gizi dan Pangan 3: 1-12.

Suryana, Achmad. 2004. Ketahanan Pangan Indonesia dalam Prosiding Widyakarya Nasional Pangan dan Gizi viii. Jakarta. 